\title{
The right to be allowed to die
}

\author{
A G M Campbell Department of Child Health, University of Aberdeen
}

\section{Author's abstract}

The unbridled use of modern medical skills and technology in preserving life at all costs has stimulated interest in expressing a 'right to die' by the legally competent patient who is anxious to protect his autonomy. Some recent decisions by American courts are seen to threaten this 'right to die' of competent patients and imply that legally incompetent patients including children should not have this right under any circumstances, even when expressed on their behalf by guardians, nearest relatives or parents. It is argued that this is contrary to 'natural justice' as viewed by most people. It should be possible to develop procedures which are protective of the basic 'right to life' of the incompetent yet will recognise circumstances where they could be allowed to die. This paper was presented at the 1983 annual conference of the London Medical Group, 'Human Rights in Medicine'.

What parents fear more than anything else is that their baby, on whom they had pinned such hopes, will be born severely abnormal or damaged, will be condemned to a lifetime of crippling disability and will never achieve independence. What many old people fear even more than death itself is a lingering period of physical and mental deterioration which inevitably will lead to a loss of control over their bodies and create heavy burdens for their families. At these opposite 'edges of life' (1) modern medicine, with its technological marvels, has made the survival of severely handicapped infants and a prolonged vegetative fate for the dying increasingly likely possibilities. Doctors are losing control over their technology and patients are losing their autonomy through the sometimes misguided and not always well-meaning interventions of assorted individuals and pressure groups insisting that treatment be continued as long as possible in defence of the 'sanctity of life'. Doctors understandably afraid of the possible legal implications of their actions are increasingly being forced to put their own interests

\section{Key words:}

Right to die; autonomy; medical ethics; 'living wills'; refusal of medical treatment. before those of their patients by practising defensively and continuing treatment far beyond what seems to be justified clinically. In the long-term this trend must be bad for everyone.

\section{Transatlantic contrasts}

In this country, at least as far as the aged are concerned, doctors and families are still relatively free from such interventions although recent cases involving infants give cause for concern (2). In an editorial Bayliss has stated 'In Britain, sound unhurried clinical judgment (supported when necessary by other specialists), sympathy, understanding and mutual trust, rather than abstract principles and printed policy statements have in general stood patients in good stead' (3). In the United States the dilemma, 'to save or let die' has become a major preoccupation involving doctors, nurses, social workers, lawyers, professional ethicists of all kinds, the general public and the legislators.

\section{The 'right' to live or die}

It is doubtful if absolute 'rights', moral or legal, either to life or to death can exist in any modern society. 'Rights' must be relative to responsibilities and obligations and will depend on circumstances. Nevertheless, the 'right to die' has become the slogan of those who insist on their right to refuse life-saving treatment; or to commit suicide (a separate debate).

Actual or potential patients, while still of sound mind, are being forced to exercise this right by drawing up 'living wills' in the hope that these will protect them from cruel and pointless treatment (4). Through a 'living will', a patient can instruct his nearest relative, guardian, or best friend, someone he can trust, as to the kind of care he would like in his final days and in the manner of his dying. It is to be hoped that the growing hospice movement will do much to eliminate this macabre exercise.

\section{American case law}

Most, if not all, of us probably would agree that a mentally sound adult patient's expressed wish not to be treated should always be respected. This view is generally accepted in common law and for doctors to treat a patient against his or her will could be regarded as an assault. In the difficult dilemmas involving the 
limits of treatment there are no authoritative guidelines to help doctors. Much is still left to the doctor's discretion, to trust in his knowledge and to his judgment of what seems best for the patient. This quaint, old-fashioned and much maligned paternalism which in so many ways is still a feature of British medicine has largely disappeared from hospital practice in the United States, not always or even often to the patient's advantage. In the United States there is a growing case law that, to me at least, makes disturbing reading. More and more the courts are being involved in these very individual and complex issues by patients who don't trust their doctors; by doctors who don't trust their patients; by administrators who are scared of the institutional implications; by District Attorneys and other lawyers seeking personal or political advantage and, I am sorry to say, by doctors who are only too eager to pass the buck. Even the 'right to die' of the competent has been challenged, some courts ruling that there is no constitutional right to die. If it is difficult enough for the mentally sound adult it is much worse for those unfortunate enough to be incompetent legally - the mentally handicapped, the mentally ill, infants and children. To insist, as many do, on the absolute 'right to life' of the incompetent, including children, is to deprive them of any 'right' to die, or more accurately any 'right' to be allowed to die.

Many in this country will have heard of Karen Quinlan; some may have heard about Saikewicz and about Brother Fox, all cases which have been deliberated in American courts $(5,6)$. They illuminate the unhappy and uncertain interface that can exist between medicine and the law. Annas has written 'When a judge decides to play legislator on issues like the termination of treatment, in which there are strong and competing social values, and case law is embryonic, the result is likely to be very unsatisfactory indeed'. How unsatisfactory can be illustrated by considering two other cases $(7,8)$.

Fohn Storar was a profoundly retarded 52-year-old resident of an institution for the mentally handicapped. His mental age was 18 months. His mother, a 77 -yearold widow, visited him regularly. In July 1979, John Storar was diagnosed as having bladder cancer and his mother was appointed his legal guardian so that she could consent to $x$-ray therapy. This produced a remission, but nine months later there was a relapse with severe bladder haemorrhage unresponsive to cautery. By this time he had secondary tumours in his lung and was considered to be inoperable and terminal. The doctors asked his mother for permission to administer blood transfusions. She agreed to this only reluctantly, but two months later she asked that the transfusions, necessary every two weeks, be stopped and that her son be allowed to die. The director of the State facility for the handicapped then petitioned the court for authorisation to continue the blood transfusions. Mrs Storar opposed the petition. In court all agreed that John Storar could not understand what was happening to him, that he had irreversible bladder cancer and that even with blood transfusions he could live only three to six months. The transfusions upset him greatly; he had to be sedated and restrained and he had severe pain from clots on passing urine. Without the transfusions he would become progressively weaker from anaemia and die. The lower court concluded that, under the circumstances, $\mathrm{Mr}$ Storar's right to refuse treatment could be exercised by his mother because she was in the best position to determine what he would want, but the New York Court of Appeal reversed the decision on the grounds that there was no realistic way to determine what John Storar himself would want done. The court concluded that since John Storar was mentally an infant, he must be afforded the same rights as an infant. That is, he had no right to die.

The Danville Twins. In May, 1981, in the local hospital in Danville, Ohio, twins were expected. Two doctors were in attendance - the obstetrician and the family doctor. After some difficulty the twins were born, asphyxiated but alive. It was found that they were joined at the waist and shared three legs - they were Siamese twins. The obstetrician and the father (who was present at the birth and was also a doctor) exchanged glances and the obstetrician ordered that the twins were not to be resuscitated, but were to be transferred to the nursery, where they were to be kept comfortable and allowed to die. The order 'Do not feed, in accordance with the parents' wishes' was written in the medical record. In the usual course of events, and as has happened in similar tragedies with severely malformed infants countless times before in hospitals up and down the land, in the United States and elsewhere, the babies would have died peacefully some hours or days later. The parents would have passed through the intense grieving process that accompanies the loss of a much wanted baby when the anticipated joy of a new birth is suddenly changed to tragedy. They would never have forgotten the experience, but in time the pain would have lessened and in a year or two they would likely have had another child - a normal child. Family life would have gone on, as it must. But that did not happen. An anonymous caller telephoned the Illinois Department of Children and Family Services and complained that the twins were being neglected. A social worker was sent to investigate. A petition of neglect against the parents was taken out in local court and the judge awarded custody of the twins to family services. Against the wishes of the parents the twins were moved to a teaching hospital. Three weeks later the District Attorney filed criminal charges against the parents and the responsible doctor for conspiracy to commit murder - the first time in the United States that criminal charges had ever been filed against parents and doctors for withholding food or medical treatment from a newborn infant with birth defects. (This was three months after a paediatrician in England was committed for trial on a similar charge, again 
apparently as the result of an anonymous telephone call). When it came to the preliminary hearing in the twins' case none of the nurses was willing to link the parents and physicians directly with orders to withhold food so that with lack of evidence the judge dismissed the charges. Nevertheless, the District Attorney insisted on pressing on with attempts to reinstate charges by presenting the case to a Grand Jury and as far as I am aware the arguments still go on.

\section{Leadership and 'due process'}

For me, the more depressing aspect of these cases is the apparent lack of strong medical leadership and the absence of professional and public outrage at such apparent miscarriages of natural justice. In the case of John Storar where were the doctors willing to make decisions, based primarily on what seemed beyond reasonable doubt, as to what was in the best interests of their patient? For the twins the doctors made a decision, but one that can be criticised as being too hasty, arbitrary and based on inadequate knowledge at the time. While it may have been the right decision, it was not arrived at through what might be called 'due process'.

Doctors have long been trusted with starting and stopping treatments in the patient's best interests. Society (in the form of the law) has rarely intervened in what are intensely individual and private matters between doctors and families. This practice coupled with the traditional Western ethic based on our JudaeoChristian heritage of respect for life and the commitment of doctors to preserve life have ensured that abuses of this trust are rare events. The twentieth century has seen an unprecedented expansion in knowledge and technology that has changed the whole meaning of life and death. We can start life artificially and we have had to re-define death. Death can no longer be viewed as a simple event that we accept as part of life itself which, sadly in most cases, we are relatively powerless to influence. Nowadays dying can be a long drawn-out process, affected by our actions to an extent scarcely imagined by our medical forebears. At the same time, we have had to recognise a growing social emphasis not on the fact of life itself, but on the quality of life to be lived. Thus, in caring for dying or severely handicapped persons two opposing philosophies can be identified (9). The first can be called 'disease orientated': it places death in the extreme negative position. The second is labelled 'person orientated' and views some kinds of severely compromised living as worse than death itself. The first philosophy is consistent with the excitement of aggressive medical interventions using new skills and technology to the utmost. It deserves credit for pushing forward the frontiers of medicine through research. It is a simple and appealing philosophy where medical and technical considerations are paramount and it is attractive to the public in general, and to the media in particular who so often seem to concentrate only on the successes - the 'miracle cures' and 'breakthroughs'.
For individual sufferers too, hope or an image of hope can be kept alive for a time at least. For enthusiastic and idealistic young doctors and nurses it offers opportunities to do what they thought they were trained for - to save lives. But the unbridled and indiscriminate use of our new-found skills and technology may merely dehumanise patients and increase suffering. Patients, families, doctors and nurses may have such unrealistic expectations of new treatments and technology that they may be blinded from confronting the difficult ethical issues intellectually and emotionally. In any case, all treatment must fail eventually.

On the other hand, while the person-orientated philosophy may protect patients from the dehumanising indignities of drips, tubes, respirators, monitors and pointless surgery and the continuing cruelties of the underlying disease, if it is accepted too easily it may lead to an undesirable degree of therapeutic inertia giving up too soon or for the wrong reasons. Thus, the application of this philosophy, while immediately appealing to the dying patient and his family and to sensitive and compassionate doctors and nurses, may be unwise, unjust and in some circumstances may be viewed as illegal. Surely some sort of typical British compromise between these two philosophical extremes is not only possible but highly desirable.

The increasing tendency to involve the courts is regrettable and not likely to be in the best interests of patients but we must recognise the validity of recent demands that doctors be more accountable for their actions. Justice must not only be done, but be seen to be done. We must adhere to 'due process' in arriving at life and death decisions through the development of general policies or broad guidelines that can be agreed within the kind of medical and moral framework that most colleagues and the majority of the public would find acceptable. If we are to 'draw lines', and we all draw lines, there must be some criteria to follow, even general ones. In addition we should welcome the help of 'a community broader than the medical community' in drawing them up (10). Previously we have described how a form of 'due process' may be achieved in caring for infants and children $(11,12)$.

\section{The incompetent patient}

Few of us would dispute the 'right to die' freely expressed by the competent patient who refuses treatment. Ian Kennedy has written that . . . 'there is no right to invade the privacy of an unwilling patient by forcing treatment . . (5). But what about the incompetent patient or child? Kennedy also states 'If the patient is legally incompetent, however, it remains a matter of lamentable obscurity whether a legal guardian or other relative can in law authorise withdrawal of treatment'. He goes on to point out that 'until a firm set of legal rules is established, the doctor will continue to hesitate'. It is little wonder that doctors are feeling vulnerable, if not downright scared, and passing the buck to the courts. If the doctor dis- 
continues treatment a relative of the patient or other interested individuals, such as moralising lobbyists, could, from a comfortable distance, instigate legal action alleging that the patient's death was due to neglect by the doctors and nurses. If the doctor presses on with treatment against his better judgment he causes further pain and suffering to his patient; much anguish for the family and a further drain on dwindling resources that may be desperately needed, even lifesaving, elsewhere.

\section{Infants and children}

For infants and children I would argue that decisions involving the withholding or withdrawing of lifesupporting care must continue to be made responsibly and compassionately in the child's interests by the doctor and parents. In other words, just because he is a child he should not be deprived of the 'right' to be allowed to die when the alternative, the continuation of treatment, would be pointless and cruel. Doctors and families have made these decisions together for generations and despite some inevitable conflicts of interests, I believe they should continue to make them. The courts should be used only as a last resort. Families, particularly parents, have the most to lose or gain and they have the most intimate knowledge of likely patient preferences and family realities - values, priorities and resources. 'These cases involve a complex interplay of clinical judgment, concern for the infant, and respect for the family which defies simple generalisations and platitudes' (13).

Fost has indicated his lack of trust in parents always putting the child's interests first and, like others, has suggested that a committee, a child advocate or the courts be used more frequently to decide these issues (14). He implies that if parents and their advising doctors allow a child to die even out of love and concern for the child's future they are neglecting the child's best interests and violating the law. But a child's best interests cannot be defined abstractly by committees or courts and what better advocate is there than the parents? The Stinsons in movingly describing their experiences as parents of a severely handicapped preterm infant who was receiving apparently endless and pointless intensive care stated:

'We believe there is a moral and ethical problem of the most fundamental sort involved in a system which allows complicated decisions of this nature to be made by people who do not have to live with the consequences of their decisions' (15).

Of course, families and parents vary in their understanding, capacity to love, ability to manage, willingness to sacrifice, etc. All paediatricians know families where the experience of caring for a very handicapped person has been fulfilling and rewarding but they also know families where it has been demoralising, divisive and destructive. We cannot easily predict how parents will cope. What is remarkable is how well most can adjust to adversity and how far they are willing to sacrifice for a handicapped but much loved family member. But if they with their doctors choose otherwise, should they not be supported unless the choice is so faulty that the doctors (and the courts) must intervene. Those who would judge these parents harshly and condemn them for allowing their child to die might reflect on how much they themselves have done towards improving the support, facilities and resources for the handicapped in their community. Doctors too will vary - in experience, knowledge and judgment, quite apart from their awareness of the ethical dilemmas involved, and the law. We have a responsibility to ensure that these issues are widely debated and shared throughout our professional lives. In recognising the importance of ethics (as well as etiquette) in the undergraduate curriculum our medical schools compare most unfavourably with those in the United States (16).

As with most medical decisions, much depends on trust, and with rare exceptions this trust appears to be justified. If these decisions are made openly, as is advocated, abuses should be easy to detect. Can we be sure that a policy based on distrust will be any better? I believe that decisions to allow certain infants and children to die are as moral as many decisions for life. With all their imperfections they must remain in the control of the family and the doctor or doctors responsible for care. To subject them to State control in misguided efforts to protect the 'rights' of infants to life would be a potentially dangerous step.

\section{'The slippery slope'}

One argument used freely by critics who oppose the whole concept of selective treatment for the damaged or deformed infant goes something like this: 'If paediatricians are allowing some infants to die in 1983, what on earth will they be up to in 1993? Doctors have embarked on the "slippery slope" towards policies reminiscent of the Nazi Holocaust.' I should be the first to agree that the dangers would be great if governments, courts or even committees were to choose either for life or for death. That risk of tyranny is one of the strongest arguments for keeping these decisions firmly centred on the family and their medical advisers. As the Rothmans have written in discussing the conflict over children's rights: 'Any one parent can only do mischief on a small scale. The State can do harm on a large scale ...'(17).

Responsible and sensitive medical leadership is essential in resolving the desperately complex and tragic dilemmas that arise when the injustices of biology hit families at their most vulnerable. Too often, sadly, it is missing at the time when parents and families need it most. The modern tendency to devalue the importance of leadership is undermining the role of the doctor in caring as well as curing. To concentrate on what can be done rather than on what should be done with new skills and technology is to avoid facing the issues squarely. This attitude must be bad for patients 
and in the long term will discredit the profession. 'Since families and patients must live with the problems one way or another in any case, the physician's failure to face the issues may constitute a victimising abandonment of patients and their families in times of greatest need' (18).

Ingelfinger has written: '. . . current attempts to demysticise and debase the status of the physician are compromising his ability to provide leadership (not exercise dictatorship) when health and life are at stake a function that may be the most important service that the physician renders to society' (19).

\section{References}

(1) Ramsey P. Ethics at the edges of life. Medical and legal intersections. New Haven and London: Yale University Press, 1978.

(2) Anonymous. The right to live and the right to die. (editorial). British medical journal 1981; 283: 569-570.

(3) Bayliss R I S. Thou shalt not strive officiously. British medical journal 1982; 285: 1373-1375.

(4) Bok S. Personal directions for care at the end of life. New England journal of medicine 1976; 295: 367-369.

(5) Kennedy I M. The Karen Quinlan case: problems and proposals. Fournal of medical ethics 1976; 2: 3-7.

(6) Annas G J. Quinlan, Saikewicz and now Brother Fox. Hastings Center report 1980; 10, 3: 20-21.
(7) Annas G J. Help from the dead: the cases of Brother Fox and John Storar. Hastings Center report 1981; 11, 3: 19-20.

(8) Robertson J A. Dilemma in Danville. Hastings Center report $1981 ; 11,5: 5-8$.

(9) Duff R S, Campbell A G M. On deciding the care of severely handicapped or dying persons: with particular reference to infants. Pediatrics $1976 ; 57: 487-493$.

(10) McCormack R A. To save or let die. The dilemma of modern medicine. Fournal of the American Medical Association 1974; 229: 172-176.

(11) Campbell A G M, Duff R S. Deciding the care of severely malformed or dying infants. Fournal of medical ethics 1979; 5: 65-67.

(12) Campbell A G M. Which infants should not receive intensive care? Archives of disease in childhood 1982; 57: 569-571.

(13) Healey J M. The rights of minors and the rights of parents revisited III. Connecticut medicine 1982; 46: 227.

(14) Fost N. Counseling families who have a child with a severe congenital anomaly. Pediatrics 1981; 67: 321-324.

(15) Stinson R, Stinson P. On the death of a baby. Fournal of medical ethics 1981; 7: 5-18.

(16) Veatch $R$ M. Medical ethics teaching: report of a national medical school survey. Fournal of the American Medical Association 1976; 235: 1030-1033.

(17) Rothman D J, Rothman S M. The conflict over children's rights. Hastings Center report 1980; 10, 3: 7-10.

(18) Duff R S, Campbell A G M. Moral and ethical dilemmas in the special care nursery. New England journal of medicine 1973; 289: 890-894.

(19) Ingelfinger F J. Bedside ethics for the hopeless case. New England journal of medicine 1973; 289: 914-915. 